\title{
Early Higher Achieved Mean Arterial Pressure Is Not Associated with Clinical Outcomes after Cardiac Arrest: A systematic Review and Meta-analysis
}

\section{Wen Jie Wang}

Cangzhou Central Hospital

\section{Shun Yi Feng}

Cangzhou Central Hospital

\section{Su Li Zhang}

Cangzhou Central Hospital

Yong Li ( $\sim$ ly13333367871@hotmail.com )

Cangzhou Central Hospital https://orcid.org/0000-0002-2268-6205

\section{Research}

Keywords: mean arterial pressure, cardiac arrest, neurological outcomes

Posted Date: August 17th, 2020

DOI: https://doi.org/10.21203/rs.3.rs-56030/v1

License: @ (i) This work is licensed under a Creative Commons Attribution 4.0 International License. Read Full License 


\section{Abstract}

Purpose: This study investigated the effect of early higher achieved mean arterial pressure (MAP) on clinical outcomes after cardiac arrest (CA).

Methods: PubMed, ScienceDirect, Web of Science, China National Knowledge Infrastructure, and Wanfang databases were searched for relevant articles until May 2020. The meta-analysis produced pooled effect size represented by odds ratios (ORs) and corresponding $95 \%$ confidence intervals (Cls).

Results: Nine studies that enrolled 1337 participants were considered eligible for this meta-analysis. Early higher achieved MAP was associated with similar mortality (OR 0.54, 95\% $\mathrm{Cl} 0.26-1.12 ; p=0.10$ ), neurologic outcome (OR 1.30, 95\% Cl $0.65-2.58 ; p=0.46)$, length of ICU stay (OR $-0.06,95 \% \mathrm{Cl}-0.31-0.19 ; p=0.46)$, mechanical ventilation time (OR $-0.14,95 \% \mathrm{Cl}-0.90-0.62 ; p=0.72$ ), and bleeding (OR $0.57,95 \% \mathrm{Cl} 0.23-1.40 ; p=0.22$ ) compared with low MAP. Sensitivity analysis demonstrated that the result was solid. No publication bias across the studies was observed using Begg's and Egger' funnel plot plot.

Conclusion: Based on current evidence, this meta-analysis confirmed that early higher achieved MAP does not improve the clinical outcomes after CA.

REGISTRATION: (PROSPERO: CRD42020189875)

\section{Introduction}

Cardiac arrest (CA) is a major public health concern and a leading cause of death worldwide and has claimed more than 17 million lives annually.[1] Only $10 \%$ of patients who underwent CA can survive hospitalization,[2] and $5 \%$ experience full neurologic recovery;[3] many survivors are discharged with a poor functional status.

Early post-arrest care in CA is an important step in the chain of survival. An adequate mean arterial pressure (MAP) may be beneficial to maintain organ blood flow and sufficient oxygen delivery to meet oxygen demands in the brain, heart, and other organs. Current guidelines recommend targeting MAP of $65 \mathrm{mmHg}$ in patients post-CA during ICU stay. These guidelines are based on the assumption that post-CA syndrome is a sepsis-like syndrome. The post-CA syndrome is a distinct and more complex entity than the sepsis-like syndrome alone; in this regard, aiming for the same hemodynamic goals is probably oversimplification.

Several studies[4-12] assessed early high versus low MAP target for neurologic outcome after CA; However, whether the use of vasoactive drugs to achieve higher MAP will increase survival remains unknown. In the present work, we performed an updated meta-analysis to evaluate early high achieved MAP target for clinical outcomes after CA.

\section{Methods}

\section{Study design}

This systematic review and meta-analysis were performed based on the guidance of the Preferred Reporting Items for Systematic Reviews and Meta-analysis statement.[13] No ethical approval and patient consent are required because all analyses are based on previously published studies. The protocol for this review was 
registered in advance with PROSPERO (International Prospective Register of Systematic Reviews; CRD42020189875).

\section{Literature search}

PubMed, ScienceDirect, Web of Science, and China National Knowledge Infrastructure were comprehensively searched from inception to May 2020 to locate potential articles that assessed early high achieved MAP for clinical outcomes after CA. The search terms included "mean arterial pressure target" and "cardiac arrest" The bibliographies of previous reviews and included studies were also manually searched to identify other potentially eligible trials.

Studies were considered eligible if they met the following criteria: (1) studies that focused on early high versus low MAP target for clinical outcomes after CA; and (2) studies with complete information for the assessment of odds ratios (ORs) with 95\% confidence intervals (Cls). In cases where no overlap of the study population or enrollment period in articles published by the same investigators existed, the article with the greatest number of patients was used for the analysis. The exclusion criteria were as follows: (1) studies published repeatedly; (2) reviews, conference abstracts, letter, or case reports; and (3) studies without available data for statistical analysis.

\section{Data Extraction And Quality Assessment}

Two authors carefully extracted the following information from each study. The data extraction sheet was prepared to collect information on the first author, year of publication, study design, sample size, population characteristics, type of intervention, measured outcomes, and respective numerical values. When necessary and feasible, the authors of the included studies were contacted to obtain additional information. A cerebral performance category (CPC) score of 3,4 , or 5 or modified Rankin scale (mRS) of 4 or 5 was considered poor neurological outcome.

The Cochrane risk of bias tool was used to assess the design, conduction, and outcomes of the included RCTs. [14] The Newcastle-Ottawa Scale was used to assess the selection, comparability, and outcomes of the observational studies.[15] If discrepancies were observed in the data collection or assessment of the risk of bias, then the review authors resolved the disagreements through discussion.

\section{Statistical analysis}

Statistical analyses were performed using Review Manager 5.3 (The Nordic Cochrane Center, The Cochrane Collaboration, Copenhagen, Denmark) and Stata version 14 (StataCorp., College Station, TX, USA). The OR was used to denote the results with $95 \% \mathrm{Cl}$, indicating the strength of association between MAP and outcomes. The between-study heterogeneity indices were Cochran's $Q$ and $R$. If $R<50 \%$ and $p>0.1$, then the studies had no heterogeneity overall, and a fixed-effect model was used; otherwise, a random-effect model was applied. Subgroup analysis was used to evaluate whether key covariates available from the data, including sample size, study design, duration of MAP target, or arrest location, could explain any observed heterogeneity. Sensitivity analysis was conducted to monitor the robustness of the pooled treatment effects. Begg's and Egger's tests were conducted to evaluate publication bias. Statistical significance was assumed when $p<0.05$. 


\section{Results}

\section{Literature search}

Figure 1 shows the selection process for the eligible studies. Following the removal of duplicates and the exclusion of records based on title and abstract screening, 21 studies were available for full-text review. Among these full studies, five were excluded for unavailable data, four were excluded because they were studies, and three were excluded due to duplication of data. Finally, nine studies[4-12] were included in this meta-analysis.

\section{Characteristics of the included studies and quality assessment}

The characteristics of the included studies[4-12] are outlined in Table 1. The mean age ranged from 58 years to 63 years, the proportion of male subject varied from $58-88 \%$, and the duration of MAP target was between 2 and $96 \mathrm{~h}$. Four studies [9-12] were conducted in North America, three[4, 6, 8] in Europe, and two in Asia[5]. The risk of bias assessment for each included study and the summative assessment by domain are shown in Supplementary Tables 1 and 2 . 
Table 1

Characteristics of the included studies.

\begin{tabular}{|c|c|c|c|c|c|c|c|c|}
\hline $\begin{array}{l}\text { Author } \\
\text { (Year) }\end{array}$ & Country & Design & $\begin{array}{l}\text { Sample } \\
\text { size }\end{array}$ & $\begin{array}{l}\text { Arrest } \\
\text { location }\end{array}$ & $\begin{array}{l}\text { MAP } \\
\text { target } \\
(\mathrm{mmHg})\end{array}$ & $\begin{array}{l}\text { Duration } \\
\text { of MAP } \\
\text { target }\end{array}$ & TTM & $\begin{array}{l}\text { Definition } \\
\text { of poor } \\
\text { neurologic } \\
\text { outcome }\end{array}$ \\
\hline $\begin{array}{l}\text { Grand et } \\
\text { al.[1] } \\
2020\end{array}$ & Denmark & $\begin{array}{l}\text { Randomized } \\
\text { controlled } \\
\text { study }\end{array}$ & 49 & OHCA & $\begin{array}{l}65 \text { vs. } \\
72\end{array}$ & $\begin{array}{l}48 \mathrm{~h} \\
\text { after } \\
\text { ROSC }\end{array}$ & $\begin{array}{l}36^{\circ} \mathrm{C} \\
\text { for } \\
24 \mathrm{~h}\end{array}$ & CPC 3-5 \\
\hline $\begin{array}{l}\text { Huang et } \\
\text { al.[2] } \\
2019\end{array}$ & China & $\begin{array}{l}\text { Retrospective } \\
\text { cohort study }\end{array}$ & 82 & $\begin{array}{l}\text { OHCA } \\
\text { and } \\
\text { IHCA }\end{array}$ & $\begin{array}{l}60-75 \\
\text { vs. } 80- \\
100\end{array}$ & $\begin{array}{l}36 \mathrm{~h} \\
\text { after } \\
\text { ROSC }\end{array}$ & NA & CPC 3-5 \\
\hline $\begin{array}{l}\text { Jakkula } \\
\text { et al.[3] } \\
2018\end{array}$ & $\begin{array}{l}\text { Finland } \\
\text { and } \\
\text { Denmark }\end{array}$ & $\begin{array}{l}\text { Randomized } \\
\text { controlled } \\
\text { study }\end{array}$ & 120 & OHCA & $\begin{array}{l}60-75 \\
\text { vs. } 80- \\
100\end{array}$ & $\begin{array}{l}36 \mathrm{~h} \\
\text { after } \\
\text { ROSC }\end{array}$ & $\begin{array}{l}33^{\circ} \mathrm{C} \\
\text { or } \\
36^{\circ} \mathrm{C}\end{array}$ & CPC 3-5 \\
\hline $\begin{array}{l}\text { Kilganno } \\
\text { et al.[4] } \\
2014\end{array}$ & USA & $\begin{array}{l}\text { Prospective } \\
\text { cohort study }\end{array}$ & 151 & $\begin{array}{l}\text { OHCA } \\
\text { and } \\
\text { IHCA }\end{array}$ & 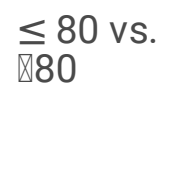 & $6 \mathrm{~h}$ & $\begin{array}{l}33^{\circ} \mathrm{C}- \\
36^{\circ} \mathrm{C}\end{array}$ & СРC 3-5 \\
\hline $\begin{array}{l}\text { Müllner } \\
\text { et al. } \\
{[5] 1996}\end{array}$ & Austria & $\begin{array}{l}\text { Retrospective } \\
\text { cohort study }\end{array}$ & 136 & OHCA & $\begin{array}{l}\leq 100 \\
\text { vs. } \otimes 100\end{array}$ & $\begin{array}{l}2 \text { h after } \\
\text { ROSC }\end{array}$ & NA & СРC 3-5 \\
\hline $\begin{array}{l}\text { Pitcher } \\
\text { et al.[6] } \\
2018\end{array}$ & USA & $\begin{array}{l}\text { Retrospective } \\
\text { cohort study }\end{array}$ & 220 & $\begin{array}{l}\text { OHCA } \\
\text { and } \\
\text { IHCA }\end{array}$ & $\begin{array}{l}\otimes 100 \text { vs. } \\
\geq 100\end{array}$ & $\begin{array}{l}6 \text { h after } \\
\text { ROSC }\end{array}$ & $\begin{array}{l}33^{\circ} \mathrm{C} \\
\text { for } \\
24 \mathrm{~h}\end{array}$ & СРC 3-5 \\
\hline $\begin{array}{l}\text { Roberts } \\
\text { et al.[7] } \\
2018\end{array}$ & USA & $\begin{array}{l}\text { Prospective } \\
\text { cohort study }\end{array}$ & 269 & $\begin{array}{l}\text { OHCA } \\
\text { and } \\
\text { IHCA }\end{array}$ & $\begin{array}{l}60-75 \\
\text { vs. } 890\end{array}$ & $\begin{array}{l}6 \text { h after } \\
\text { ROSC }\end{array}$ & NA & mRS 4-5 \\
\hline $\begin{array}{l}\text { Russo et } \\
\text { al. } \\
\text { [8]2017 }\end{array}$ & Canada & $\begin{array}{l}\text { Retrospective } \\
\text { cohort study }\end{array}$ & 122 & OHCA & $\begin{array}{l}\otimes 70 \text { vs. } \\
\geq 70\end{array}$ & $\begin{array}{l}96 \mathrm{~h} \\
\text { after } \\
\text { ROSC }\end{array}$ & NA & CPC 3-5 \\
\hline $\begin{array}{l}\text { Young et } \\
\text { al. } \\
\text { [9]2015 }\end{array}$ & USA & $\begin{array}{l}\text { Retrospective } \\
\text { cohort study }\end{array}$ & 188 & $\begin{array}{l}\text { OHCA } \\
\text { and } \\
\text { IHCA }\end{array}$ & $\begin{array}{l}\otimes 80 \text { vs. } \\
\geq 80\end{array}$ & $\begin{array}{l}24 \mathrm{~h} \\
\text { after } \\
\text { ROSC }\end{array}$ & $\begin{array}{l}32- \\
34^{\circ} \mathrm{C} \\
\text { for } \\
24 \mathrm{~h}\end{array}$ & CPC 3-5 \\
\hline $\begin{array}{l}\text { CA cardia } \\
\text { Scale, } N A \\
\text { restoratio }\end{array}$ & $\begin{array}{l}\text { rest, } C P C \\
\text { applical }\end{array}$ & $\begin{array}{l}\text { rebral perform } \\
O H C A \text { out-of- } \\
\text { us circulation, }\end{array}$ & $\begin{array}{l}\text { ce cates } \\
\text { pital ca }\end{array}$ & $\begin{array}{l}\text { y, MAPn } \\
\text { ac arrest } \\
\text { temper }\end{array}$ & arterial & $\begin{array}{l}\text { essure, } m \\
\text { al cardiac }\end{array}$ & $\begin{array}{l}\text { modifie } \\
\text { rrest, } R C\end{array}$ & \\
\hline
\end{tabular}

\section{Results of meta-analysis}

\section{Mortality}

Fiver studies $[4-6,10,11]$ that employed 642 patients reported the relation between MAP target and mortality. The pooled result with the random-effect model revealed that high MAP was associated with similar mortality to low MAP (OR 0.54, 95\% CI 0.26-1.12, $p=0.10 ; R^{2}=73 \%, p=0.006$; Fig. 2a). 


\section{Neurologic outcome}

Nine studies[4-12] with 1337 patients reported the relation between MAP target and neurologic outcome after discharge. The pooled result with the random-effect model showed that high MAP was associated with similar neurologic outcome to low MAP (OR 1.30, 95\% Cl 0.65-2.58, $p=0.46 ; R=86 \%, p<0.001$; Fig. $2 b$ ).

\section{Length of ICU stay}

Three studies[4-6] with 251 patients reported the relation between MAP target and length of ICU stay. The pooled result with the fixed-effect model indicated that high MAP was associated with similar length of ICU stay to low MAP (OR $-0.06,95 \% \mathrm{Cl}-0.31-0.19, p=0.46 ; P^{2}=0 \%, p=0.58$; Fig. $2 \mathrm{c}$ ).

\section{Mechanical ventilation time}

Two studies $[4,6]$ with 169 patients reported the relation between MAP target and mechanical ventilation time. The pooled result with the random-effect model demonstrated that high MAP was associated with similar mechanical ventilation time to low MAP (OR $-0.14 ; 95 \%-0.90-0.62, p=0.72 ; P^{2}=81 \%, p=0.02$; Fig. $2 d$ ).

\section{Bleeding}

Two studies $[4,11]$ with 171 patients reported the relation between MAP target and bleeding. The pooled result with the fixed-effect model demonstrated that high MAP was associated with similar bleeding to low MAP (OR $0.57,95 \% \mathrm{Cl} 0.23-1.40, p=0.22 ; R=0 \%, p=0.85$; Fig. $2 \mathrm{e}$ ).

\section{Subgroup Analysis}

To explore heterogeneity among the studies, we performed a subgroup analysis based on sample size, study design, MAP target duration, and arrest location (Table 2). However, we did not find the cause of heterogeneity in the subgroup analysis. 
Table 2

Subgroup analysis.

\begin{tabular}{|c|c|c|c|c|}
\hline & $\mathbf{N}$ & OR $(95 \% \mathrm{Cl})$ & $p$ & $R$ ( $P$ value $)$ \\
\hline \multicolumn{5}{|l|}{ Sample size } \\
\hline$<100$ & 5 & $0.90(0.38-2.16)$ & 0.81 & $80 \%(0.05)$ \\
\hline$\geq 150$ & 4 & $0.64(0.19-2.13)$ & 0.47 & $91 \%(<0.001)$ \\
\hline \multicolumn{5}{|l|}{ Study design } \\
\hline Retrospective & 6 & $1.09(0.55-2.16)$ & 0.80 & $80 \%(<0.001)$ \\
\hline Prospective & 3 & $0.37(0.13-1.09)$ & 0.07 & $75 \%(0.02)$ \\
\hline \multicolumn{5}{|c|}{ Duration of MAP target } \\
\hline$\leq 24 \mathrm{~h}$ & 4 & $0.48(0.19-1.22)$ & 0.12 & $85 \%(<0.001)$ \\
\hline$>24 \mathrm{~h}$ & 5 & $1.66(0.47-2.89)$ & 0.74 & $82 \%(<0.001)$ \\
\hline \multicolumn{5}{|l|}{ Arrest location } \\
\hline $\mathrm{OHCA}$ & 4 & $0.95(0.32-2.89)$ & 0.94 & $85 \%(<0.001)$ \\
\hline $\mathrm{OHCA}$ and IHCA & 5 & $0.65(0.25-1.73)$ & 0.39 & $89 \%(<0.001)$ \\
\hline
\end{tabular}

\section{Sensitivity Analysis And Publication Bias}

Sensitivity analysis results demonstrated that when any single study was removed, the remaining results were still significant (Fig. 3). As shown in Fig. 4, no publication bias was obtained from Begg's and Egger' funnel plot across the studies $(p=0.917 ; p=0.535)$.

\section{Discussion}

This systematic review summarize and re-assess the data of previous studies and explore early higher achieved MAP for clinical outcome after CA. The result showed that early higher achieved MAP is not associated with clinical outcome after CA.

Jakkula et al.[6] reported that early higher achieved MAP did not affect the serum concentration of neuronspecific enolase, S100B protein, cardiac troponin, regional frontal cerebral oxygenation, and epileptic activity on the electroencephalography. Ameloot et al.[16] did not find the benefits of a higher MAP target assessed by magnetic resonance imaging of the cerebrum. Compared with the standard MAP regimen, targeting high MAP in the first hours of an experimental ECPR model did not result in any hemodynamic improvement nor in a decrease in the amount of infused fluid.[17] These studies suggest that higher achieved MAP do not improve clinical outcomes after CA. 
Cerebral perfusion pressure (CPP) is the driving force for cerebral blood flow. CPP is defined as the difference between MAP and intracranial pressure. However, higher MAP induced by vasoconstrictors may impair regional organ perfusion, which might be undetected when monitoring arterial pressure alone. Holmgaard et al.[18] reported that higher MAP induced by vasopressors led to lower mean regional cerebral oxygenation and more frequent and pronounced cerebral desaturation during cardiopulmonary bypass. Kisser et al.[19] reported relative ratios of cerebral blood flow in the left dorsolateral and orbital prefrontal cortex and the left temporal cortex decreased with increasing systolic blood pressure; cerebral blood flow also decreased in the left dorsolateral prefrontal cortex with increasing DBP. Under brain injury, cerebral blood flow autoregulation plateau to the left and allow lower MAP, and increasing MAP with the application of vasopressor agents might be potentially harmful if the patient exceeds the upper limit pressure of autoregulation.[20,21]

Grand et al.[4, 22] observed a trend toward preserved renal function in the high MAP group, as illustrated by a trend towards higher eGFR and less need for renal replacement therapy in the high MAP target group. Early higher achieved MAP increased the urine volume and reduced the use of diuretics for pulmonary edema. This finding indicated that different organs may need different blood pressure levels after CA.

Identifying the optimal MAP for the overall patient population may be complicated by individual patient variability because baseline blood pressure varies among patients. Roberts et al.[10] reported that the association between MAP greater than $90 \mathrm{mmHg}$ and good neurologic outcome was found to be stronger among subjects with a previous diagnosis of hypertension compared with those without hypertension. In the absence of definitive data, the European Resuscitation Council guidelines recommend targeting MAP that achieves adequate urine output ( $1 \mathrm{ml} / \mathrm{kg} /$ hour) and normalization or downtrend in plasma lactate.

This meta-analysis has several important limitations. First, a recognized limitation of our study is the obvious heterogeneity with regard to the baseline characteristics of the participants, study-specific resuscitation protocols, definition of the outcomes, and follow up duration. Second, most of the included studies were nonrandomized controlled trials at risk of bias, particularly confounding and selection bias. Lastly, we were not able to assess publication bias or perform meta-regression due to the low number of the included articles.

\section{Conclusion}

Current evidence showed early higher achieved MAP is not associated with clinical outcome after CA. Although the results of this meta-analysis were limited by the heterogeneity among the studies, in the absence of large randomized controlled trials, the pooled analysis represents the best available method of assessing early higher achieved MAP for clinical outcomes after CA.

Abbreviations:

$\mathrm{CA}=$ cardiac arrest, $\mathrm{CI}=$ confidence interval, $\mathrm{CPC}=$ cerebral performance category, $\mathrm{CPP}=$ cerebral perfusion pressure, $\mathrm{CPR}$ = cardiopulmonary resuscitation, IHCA in-hospital cardiac arrest, MAP = mean arterial pressure, NOS = Newcastle-Ottawa Scale, OHCA = out-of-hospital cardiac arrest, OR = odds ratio, ROSC = restoration of spontaneous circulation

\section{Declarations}




\section{Conflict of interest}

The authors declare no conflict of interest.

\section{Availability of data and materials}

The datasets used and/or analyzed during the current study are available from th corresponding author on reasonable request.

\section{Consent for publication}

Not applicable to a systematic review

Ethics approval and consent to participate

Not applicable to a systematic review.

\section{Funding}

This research did not receive any specific grant from funding agencies in the public, commercial, or not-for-profit sectors

\section{Author Contributions}

SYF, SLZ and YL contribute to study design and literature search.

\section{References}

1. Mozaffarian D, Benjamin EJ, Go AS, Arnett DK, Blaha MJ, Cushman M, de Ferranti S, Després JP, Fullerton HJ, Howard VJ, et al. Heart disease and stroke statistics-2015 update: a report from the American Heart Association. Circulation. 2015;131(4):e29-322.

2. Mozaffarian D, Benjamin EJ, Go AS, Arnett DK, Blaha MJ, Cushman M, Das SR, de Ferranti S, Després JP, Fullerton HJ, et al. Executive Summary: Heart Disease and Stroke Statistics-2016 Update: A Report From the American Heart Association. Circulation. 2016;133(4):447-54.

3. Gräsner JT, Lefering R, Koster RW, Masterson S, Böttiger BW, Herlitz J, Wnent J, Tjelmeland IB, Ortiz FR, Maurer $\mathrm{H}$, et al. EuReCa ONE-27 Nations, ONE Europe, ONE Registry: A prospective one month analysis of out-of-hospital cardiac arrest outcomes in 27 countries in Europe. Resuscitation. 2016;105:188-95.

4. Grand J, Meyer AS, Kjaergaard J, Wiberg S, Thomsen JH, Frydland M, Ostrowski SR, Johansson PI, Hassager C. A randomised double-blind pilot trial comparing a mean arterial pressure target of $65 \mathrm{~mm}$ Hg versus 72 mm Hg after out-of-hospital cardiac arrest. Eur Heart J Acute Cardiovasc Care. 2020:2048872619900095.

5. Huang MM, Wei M, Xia M, Hu YY, Xie XW, Han XQ. A clinical research of the effect of mean arterial pressure on the neurological prognosis of patients after resuscitation from cardiac arrest. J Clin Emerg. 2019;20(6):450-3. 
6. Jakkula P, Pettilä V, Skrifvars MB, Hästbacka J, Loisa P, Tiainen M, Wilkman E, Toppila J, Koskue T, Bendel S, et al. Targeting low-normal or high-normal mean arterial pressure after cardiac arrest and resuscitation: a randomised pilot trial. Intensive Care Med. 2018;44(12):2091-101.

7. Kilgannon JH, Roberts BW, Jones AE, Mittal N, Cohen E, Mitchell J, Chansky ME, Trzeciak S. Arterial blood pressure and neurologic outcome after resuscitation from cardiac arrest. Crit Care Med. 2014;42(9):208391.

8. Müllner M, Sterz F, Binder M, Hellwagner K, Meron G, Herkner H, Laggner AN. Arterial blood pressure after human cardiac arrest and neurological recovery. Stroke. 1996;27(1):59-62.

9. Pitcher JH, Dziodzio J, Keller J, May T, Riker RR, Seder DB. Hemodynamic, biochemical, and ventilatory parameters are independently associated with outcome after cardiac arrest. Neurocrit Care. 2018;29(1):6976.

10. Roberts BW, Kilgannon JH, Hunter BR, Puskarich MA, Shea L, Donnino M, Jones C, Fuller BM, Kline JA, Jones $A E$, et al. Association between elevated mean arterial blood pressure and neurologic outcome after resuscitation from cardiac arrest: Results from a multicenter prospective cohort study. Crit Care Med. 2019;47(1):93-100.

11. Russo JJ, James TE, Hibbert B, Yousef A, Osborne C, Wells GA, Froeschl MP, So DY, Chong AY, Labinaz M, et al. Impact of mean arterial pressure on clinical outcomes in comatose survivors of out-of-hospital cardiac arrest: Insights from the University of Ottawa Heart Institute Regional Cardiac Arrest Registry (CAPITALCARe). Resuscitation. 2017;113:27-32.

12. Young MN, Hollenbeck RD, Pollock JS, Giuseffi JL, Wang L, Harrell FE, McPherson JA. Higher achieved mean arterial pressure during therapeutic hypothermia is not associated with neurologically intact survival following cardiac arrest. Resuscitation. 2015;88:158-64.

13. Liberati A, Altman DG, Tetzlaff J, Mulrow C, Gøtzsche PC, loannidis JP, Clarke M, Devereaux PJ, Kleijnen J, Moher D. The PRISMA statement for reporting systematic reviews and meta-analyses of studies that evaluate health care interventions: explanation and elaboration. PLoS Med. 2009;6(7):e1000100.

14. Higgins JP, Altman DG, Gøtzsche PC, Jüni P, Moher D, Oxman AD, Savovic J, Schulz KF, Weeks L, Sterne JA. The Cochrane Collaboration's tool for assessing risk of bias in randomised trials. Bmj. 2011;343:d5928.

15. Yu L, Sun Y, Shang Y, Yin M. Effect of timing of umbilical cord clamping on maternal and neonatal outcomes: A protocol for systematic review and network meta-analysis. Med (Baltim). 2019;98(16):e15283.

16. Ameloot K, De Deyne C, Eertmans W, Ferdinande B, Dupont M, Palmers PJ, Petit T, Nuyens P, Maeremans J, Vundelinckx $\mathrm{J}$, et al. Early goal-directed haemodynamic optimization of cerebral oxygenation in comatose survivors after cardiac arrest: the Neuroprotect post-cardiac arrest trial. Eur Heart J. 2019;40(22):1804-14.

17. Fritz C, Kimmoun A, Vanhuyse F, Trifan BF, Orlowski S, Falanga A, Marie V, Groubatch F, Albuisson E, Tran N, et al. High Versus Low Blood-Pressure Target in Experimental Ischemic Prolonged Cardiac Arrest Treated with Extra Corporeal Life Support. Shock. 2017;47(6):759-64.

18. Holmgaard F, Vedel AG, Lange T, Nilsson JC, Ravn HB. Impact of 2 Distinct Levels of Mean Arterial Pressure on Near-Infrared Spectroscopy During Cardiac Surgery: Secondary Outcome From a Randomized Clinical Trial. Anesth Analg. 2019;128(6):1081-8.

19. Kisser JE, Allen AJ, Katzel LI, Wendell CR, Siegel EL, Lefkowitz D, Waldstein SR. Relations of blood pressure and head injury to regional cerebral blood flow. J Neurol Sci. 2016;365:9-14. 
20. Beylin ME, Perman SM, Abella BS, Leary M, Shofer FS, Grossestreuer AV, Gaieski DF. Higher mean arterial pressure with or without vasoactive agents is associated with increased survival and better neurological outcomes in comatose survivors of cardiac arrest. Intensive Care Med. 2013;39(11):1981-8.

21. Tarvasmäki T, Lassus J, Varpula M, Sionis A, Sund R, Køber L, Spinar J, Parissis J, Banaszewski M, Silva Cardoso $\mathrm{J}$, et al. Current real-life use of vasopressors and inotropes in cardiogenic shock - adrenaline use is associated with excess organ injury and mortality. Crit Care. 2016;20(1):208.

22. Grand J, Hassager C, Winther-Jensen M, Rundgren M, Friberg H, Horn J, Wise MP, Nielsen N, Kuiper M, Wiberg $\mathrm{S}$, et al. Mean arterial pressure during targeted temperature management and renal function after out-ofhospital cardiac arrest. J Crit Care. 2019;50:234-41.

\section{Figures}
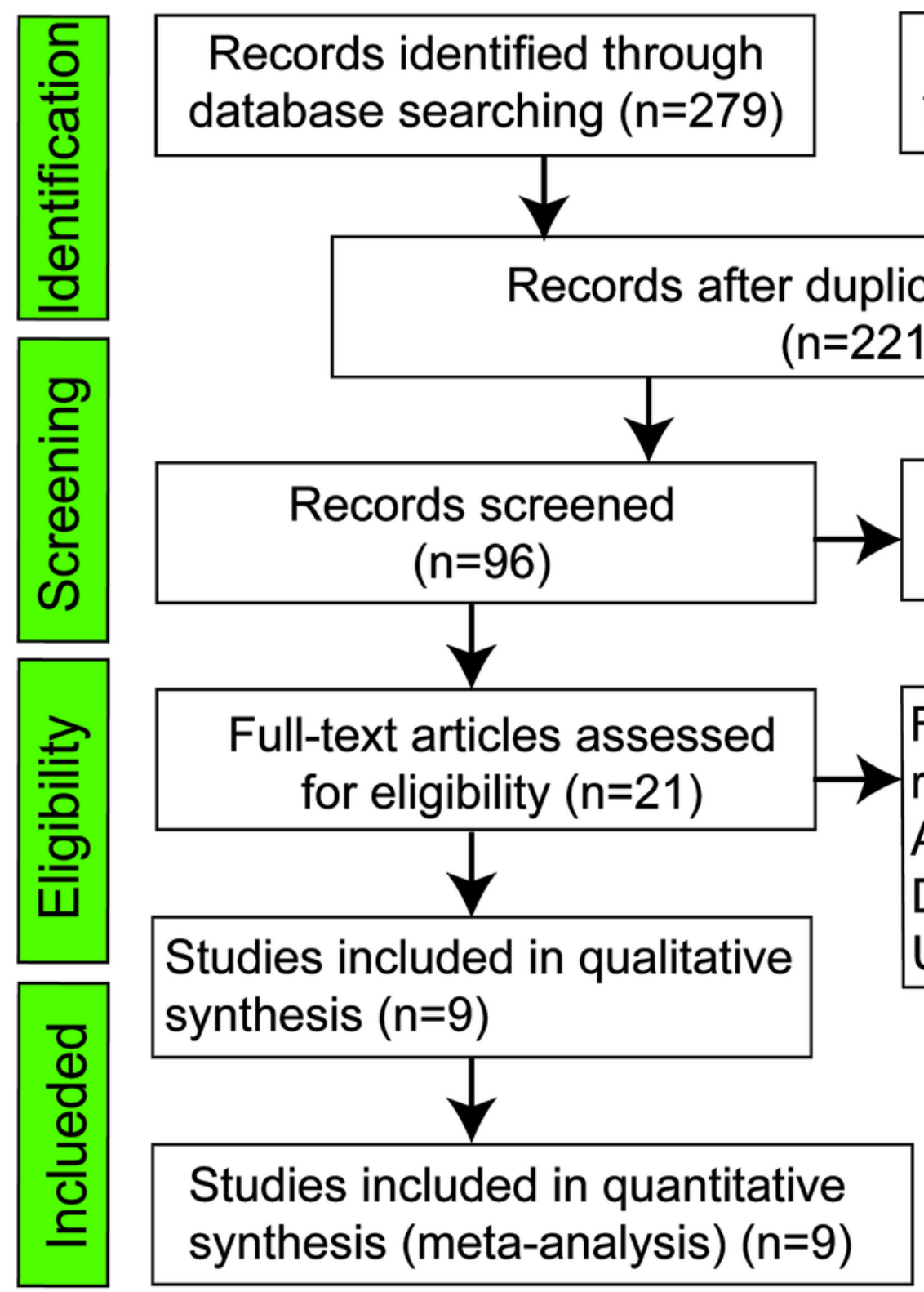

Additional records identified through other sources $(n=38)$

Records excluded $(n=75)$

Full-text articles excluded with reason:

Animal studies $(n=4)$

Duplicate data $(n=3)$

Unavailable data $(n=5)$

Figure 1 


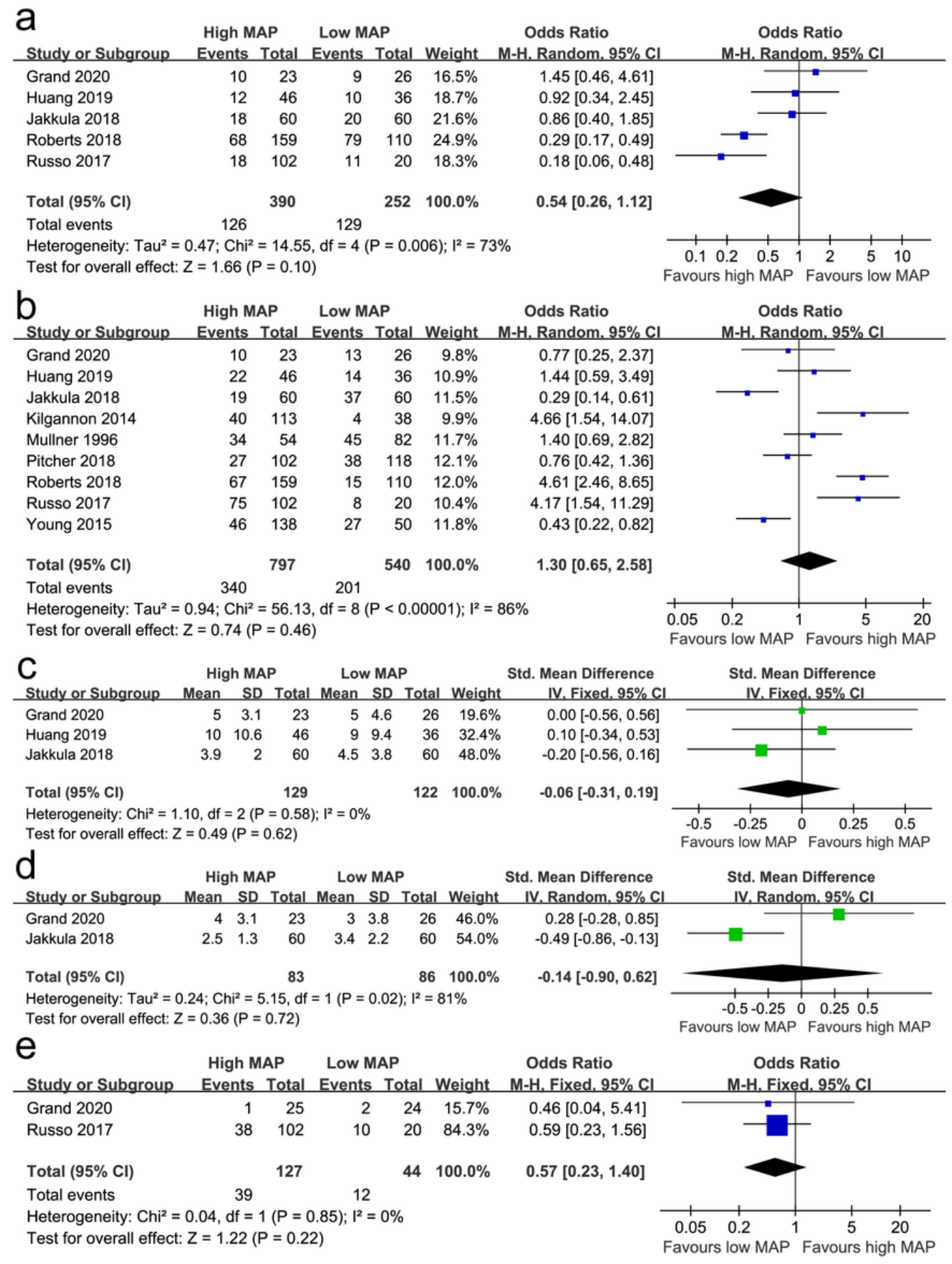

\section{Figure 2}

Forrest plot of the effect of early higher achieved mean arterial pressure on (a) mortality, (b) neurologic outcome, (c) length of ICU stay, (d) mechanical ventilation time, and (e) bleeding. 


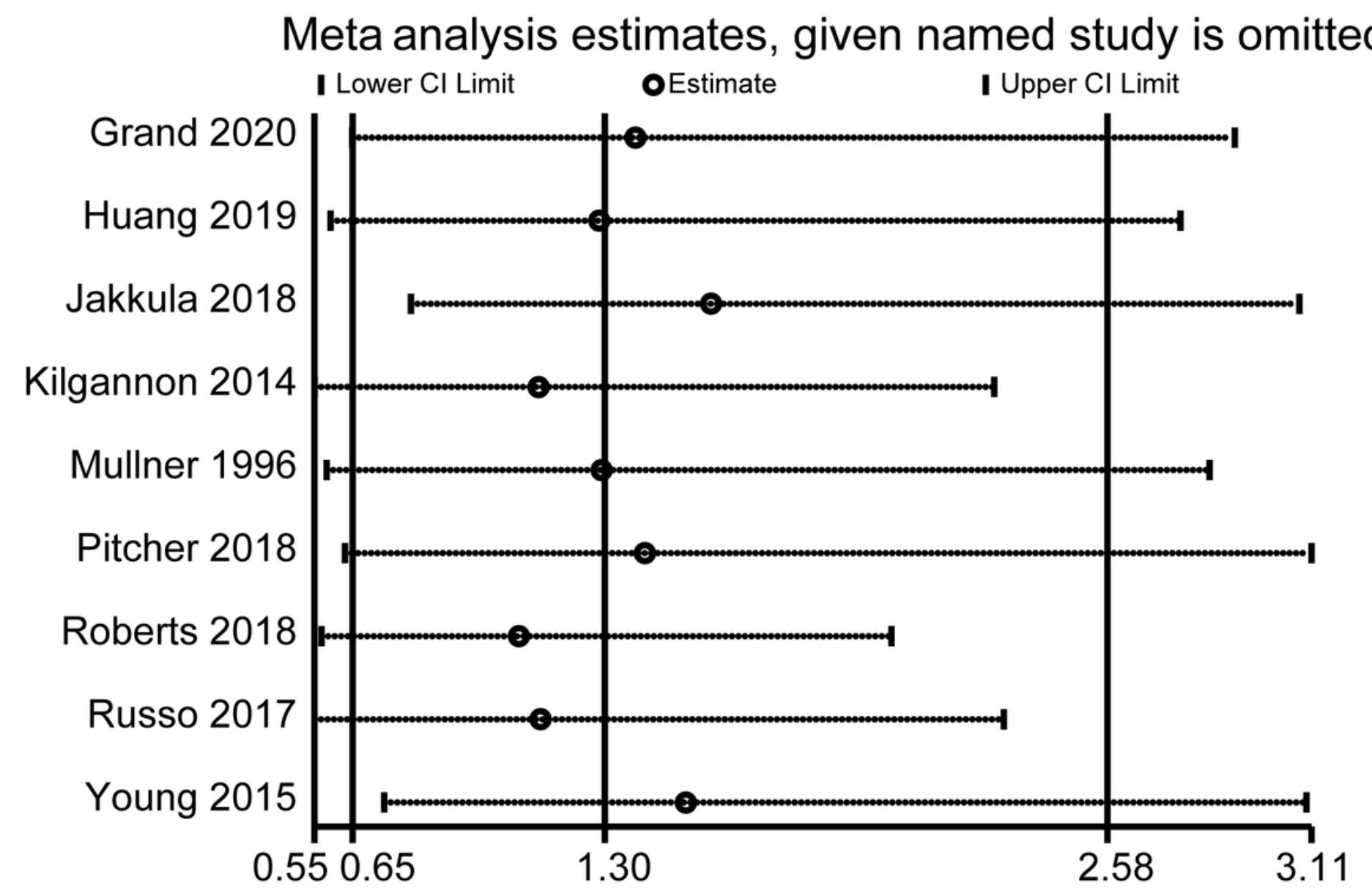

Figure 3

Results of the sensitivity analysis. 

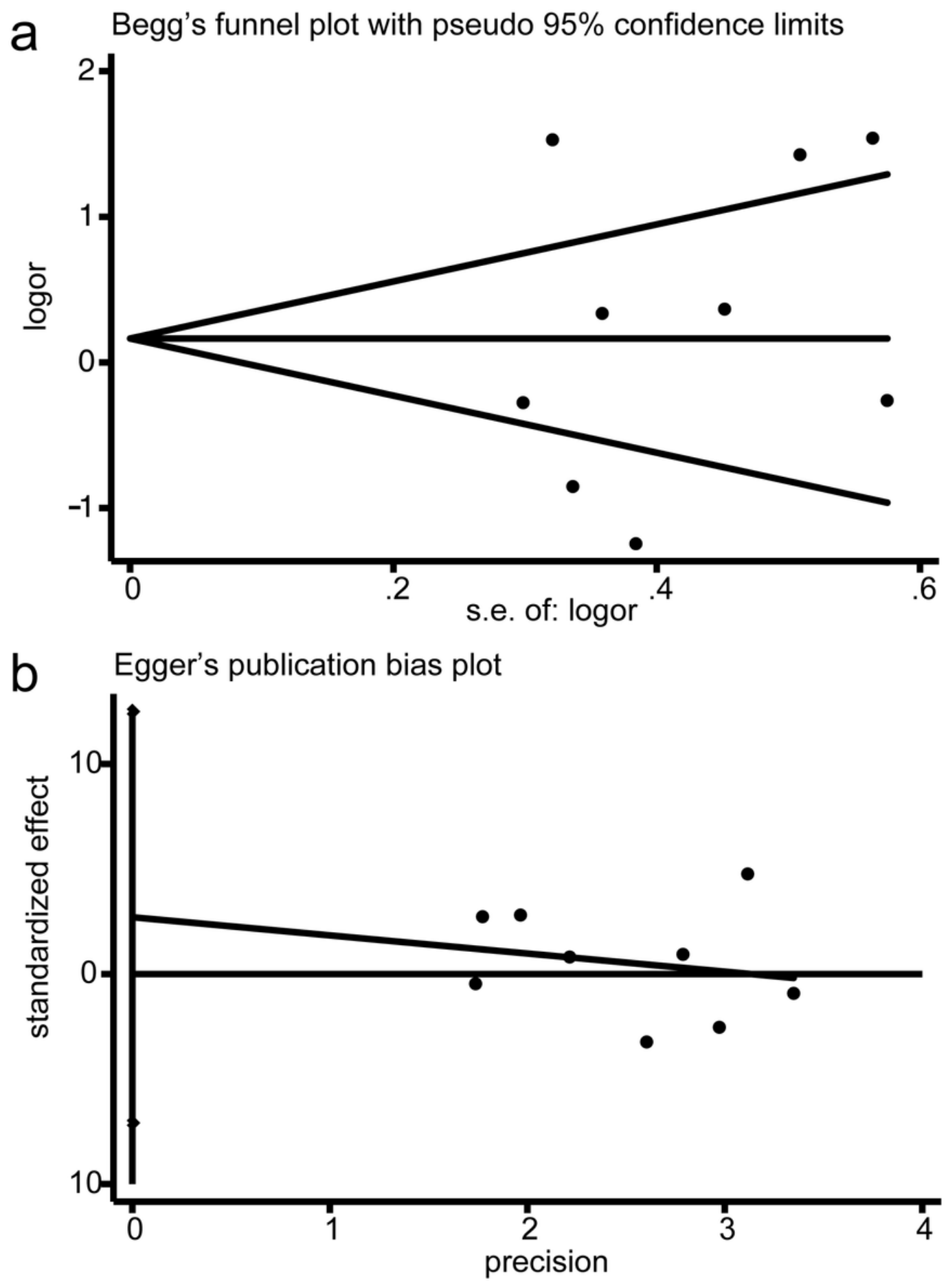

Figure 4

Funnel plot to evaluate the publication bias.

\section{Supplementary Files}

This is a list of supplementary files associated with this preprint. Click to download.

- SupplementaryTable2.docx

- SupplementaryTable1.docx 
- PRISMAchecklist.docx

Page 15/15 